\title{
Perlindungan Hukum Bagi Para Pihak Dalam Penggunaan Fitur PayLater Pada Aplikasi Gojek
}

\author{
Nisrina Anrika Nirmalapurie \\ Nisrinaan27@gmail.com \\ Universitas Airlangga
}

Keywords:
Consumer
Protection;
Peer to peer
Lending; Dispute
Resolution.

\begin{abstract}
PayLater is a method of payment in the form of loans which is currently known as peer to peer lending. Peer to peer lending is a form of loan from person to person through a non bank services. PayLater on Gojek application is a method of payment in the form of loan that can be used by users to pay for services provided by Gojek or parties who worked with Gojek. The parties involved in the use of PayLater on Gojek Application are Findaya in collaboration with Gojek in managing PayLater, the lender that give his/her authority to Findaya to distribute the fund, and the borrower. The main agreement that is formed from the use of PayLater on Gojek Application is Loan Agreement between the lender and the borrower and Consumer Agreement between the borrower and Findaya. Dispute resolution that can be done by the parties when they feel disadvantaged by other parties in the agreement is submit a request for compensation to the party concerned, file a lawsuit to Badan Penyelesaian Sengketa Konsumen, Lembaga Alternatif Penyelesaian Sengketa, or District Court.
\end{abstract}

Kata Kunci:

Perlindungan

Konsumen;

Pinjaman P2P;

Penyelesaian

Sengketa.

\begin{abstract}
Abstrak
PayLater merupakan metode pembayaran berbentuk pemberian pinjaman yang saat ini dikenal dengan sebutan Pinjaman P2P. Pinjaman P2P adalah bentuk pinjaman dari orang ke orang melalui perantara jasa keuangan non bank. PayLater pada aplikasi Gojek adalah metode pembayaran berbentuk pinjaman yang dapat digunakan oleh pengguna untuk membayar layanan yang disediakan oleh Gojek atau pihak yang bekerjasama dengan Gojek. Para pihak yang terlibat dalam penggunaan PayLater pada aplikasi Gojek adalah Findaya yang bekerjasama dengan Gojek dalam mengelola PayLater pada aplikasi Gojek, Pemberi Pinjaman yang memberikan kuasa kepada Findaya untuk menyalurkan dana yang dimilikinya, dan Penerima Pinjaman yaitu pengguna fitur PayLater pada aplikasi Gojek. Perjanjian utama dalam penggunaan PayLater pada aplikasi Gojek adalah perjanjian pinjam meminjam antara pemberi pinjaman dengan penerima pinjaman dan perjanjian konsumen antara penerima pinjaman atau pengguna fitur PayLater dengan Findaya. Upaya penyelesaian sengketa yang dapat dilakukan oleh para pihak ketika merasa dirugikan oleh pihak lain dalam perjanjian tersebut adalah mengajukan ganti rugi secara langsung kepada pihak yang bersangkutan, mengajukan gugatan ke Badan Penyelesaian Sengketa Konsumen, Lembaga Alternatif Penyelesaian Sengketa, atau ke Pengadilan Negeri.
\end{abstract}

Copyright $@ 2020$ Universitas Airlangga

\section{Pendahuluan}

PayLater adalah metode pembayaran dari Gojek berupa pinjaman dengan batas tertentu yang diberikan oleh Gojek agar pengguna dapat melakukan 
Nisrina Anrika: Perlindungan Hukum Bagi...

pembayaran layanan terlebih dahulu dan membayar tagihan pinjaman tersebut di waktu yang telah ditentukan. ${ }^{1}$ Dalam kata lain melalui fitur ini Gojek menyediakan sejumlah dana untuk digunakan oleh pengguna yang tagihannya harus dibayarkan di setiap akhir bulan menggunakan saldo GoPay. ${ }^{2}$ Dana yang disediakan oleh Gojek berbeda-beda bagi tiap pengguna, semakin sering pengguna menggunakan aplikasi Gojek maka semakin besar dana pinjaman yang akan diberikan oleh Gojek. Hal ini menunjukkan bahwa upaya manajemen risiko dari Gojek dalam memberikan pinjaman adalah dengan melihat loyalitas dari pengguna.

Pembayaran menggunakan fitur PayLater untuk saat ini dikenakan biaya oleh Gojek sebesar Rp 25.000,- per bulan dan keterlambatan pembayaran akan dikenakan denda sebesar Rp 2.000,- per hari. Upaya yang dapat dilakukan pengguna untuk mendapatkan fitur PayLater yaitu pengguna harus mengupgrade fitur Gopay pada aplikasi Gojek dengan mengunggah foto KTP bersama foto diri, setelah itu pengguna hanya perlu terus menggunakan aplikasi Gojek sampai Gojek memunculkan fitur tersebut pada aplikasi pengguna lalu pengguna dapat mengaktifkan fitur tersebut untuk dapat menggunakannya.

Ketentuan mengenai besaran dana yang dipinjamkan serta biaya-biaya lain yang perlu dibayarkan oleh pengguna ketika menggunakan metode pembayaran PayLater dituangkan dalam suatu perjanjian baku yang disediakan oleh pihak Gojek ketika pertama kali fitur metode pembayaran PayLater muncul pada aplikasi pengguna. Pengguna yang memilih untuk mengaktivasi fitur tersebut dianggap telah menyetujui perjanjian baku yang telah disediakan sebelumnya. Keberadaan dari kontrak baku bukan merupakan hal baru dalam dunia usaha namun persetujuan perjanjian oleh pengguna melalui aktivasi metode pembayaran merupakan suatu perkembangan dari bentuk persetujuan perjanjian yang dapat mempermudah pengguna namun juga memiliki kekurangan terutama terhadap perlindungan hukum bagi pengguna sebagai konsumen.

\footnotetext{
1 Gojek, 'PayLater' <https://www.gojek.com/PayLater/>.

2 ibid.
} 
Perjanjian yang terjadi dalam penggunaan PayLater pada aplikasi Gojek tidak hanya terbatas pada perjanjian yang terjadi antara pengguna dengan Gojek, karena PayLater merupakan bentuk dari perjanjian P2P yang merupakan perjanjian pinjam meminjam dari suatu pihak ke pihak lain melalui penyelenggara selain bank maka terdapat pihak lain yang terlibat dalam penggunaan metode pembayaran PayLater dalam aplikasi Gojek, dengan adanya pihak lain tersebut memungkinkan pula untuk terdapat macam-macam perjanjian dalam penggunaan metode PayLater, dengan terbentuknya perjanjian antara para pihak maka dapat diketahui pula bahwa para pihak memiliki kewajiban untuk memenuhi prestasi terhadap pihak lain dan apabila terdapat pihak yang tidak menunaikan kewajibannya maka pihak yang lalai tersebut dianggap wanprestasi dan dapat dilakukan tindakan agar pihak tersebut melakukan kewajibannya, untuk mengetahui cara penagihan kewajiban tersebut sebelumnya perlu diketahui terlebih dahulu bentuk perikatan dan pihakpihak yang terdapat dalam penggunaan PayLater. Berdasarkan hal tersebut, maka pertanyaan penelitian pada artikel ini menguji yang pertama bagaimana hubungan hukum yang terbentuk antara para pihak dalam penggunaan fitur PayLater. Kemudian bagaimana pula upaya hukum yang dapat dilakukan para pihak apabila terdapat pihak yang tidak memenuhi kewajiban pemberian prestasi dalam perjanjian PayLater.

Pendekatan masalah yang digunakan dalam tulisan ini adalah pendekatan peraturan perundang-undangan (Statute Approach) dan pendekatan konseptual (Conceptual Approach). Pendekatan peraturan perundang-undangan dilakukan dengan menelaah peraturan-peraturan yang berhubungan dengan perlindungan konsumen terutama dalam hal perlindungan konsumen dalam sektor Jasa Keuangan Teknologi Finansial. Pendekatan konseptual dilakukan dengan menelaah konsep-konsep perjanjian dan perlindungan konsumen untuk dapat mengetahui hubungan hukum yang terjadi antara para pihak dalam penggunaan fitur PayLater pada aplikasi Gojek. 
Nisrina Anrika: Perlindungan Hukum Bagi...

\section{Para pihak dalam penggunaan fitur PayLater pada aplikasi Gojek}

Perlu diketahui terlebih dahulu pengertian dari fitur PayLater yang terdapat dalam aplikasi Gojek untuk dapat mengetahui karakteristik kontrak dalam penggunaan fitur PayLater. PayLater merupakan produk hasil kerjasama antara Gojek dengan Findaya sebagai perusahaan penyelenggara pinjaman P2P yang telah terdaftar di Otoritas Jasa Keuangan dengan surat tanda bukti terdaftar nomor S-7/ NB.11/2018 tanggal 8 Januari 2018 dibawah naungan PT Mapan global Reksa. ${ }^{3}$

PayLater merupakan bentuk dari Pinjaman P2P atau juga dikenal dengan istilah peer to peer lending. Pinjaman P2P adalah kegiatan pinjam meminjam yang dilakukan oleh pemberi pinjaman dengan penerima pinjaman melalui perantara selain bank yang dikenal dengan istilah penyelenggara atau platform peer to peer lending. ${ }^{4}$ Penyelenggara pinjaman P2P merupakan penyedia jasa keuangan di sektor industri keuangan non bank, hal ini sesuai dengan pasal 1 angka 5 POJK nomor 12 tahun 2017. Penyelenggara layanan dalam layanan pinjaman P2P menjadi fasilitator untuk mempertemukan penerima pinjaman dengan pemberi pinjaman dan mewakili tindakan pemberi pinjaman berdasarkan pemberian kuasa seperti yang diatur dalam pasal 1792-1819 BW untuk melakukan tindakantindakan yang diperlukan dalam kegiatan pinjam meminjam seperti pencairan dana dan penagihan utang.

Berdasarkan terms $\mathcal{E}$ conditions yang dapat dilihat sebelum aktivasi fitur PayLater dijelaskan bahwa pengertian PayLater adalah fitur dalam aplikasi Gojek yang memberikan fasilitas pinjaman berbasis teknologi informasi yang disediakan oleh para pemberi pinjaman kepada pengguna fitur PayLater melalui Findaya sebagai Penyelenggara Pinjaman P2P. Penggunaan layanan ini hanya dapat berlaku terhadap transaksi yang dilakukan melalui aplikasi Gojek.

Maka dapat diketahui bahwa PayLater merupakan salah satu pilihan metode pembayaran dalam aplikasi Gojek yang menawarkan pinjaman dana untuk

\footnotetext{
${ }^{3}$ Otoritas Jasa Keuangan, ‘Daftar Perusahaan Fintech Lending Berizin Dan Terdaftar Di OJK per 7 Agustus 2019' (2019) <www.ojk.go.id>.

${ }^{4}$ al . Ratna Hartanto [et., 'Hubungan Hukum Para Pihak Dalam Peer to Peer Lending' (2008) 25 Jurnal Hukum Ius Quia Iustum.
} 
membayar layanan terlebih dahulu dan hanya dapat digunakan untuk pembayaran melalui aplikasi Gojek. Dana yang dipinjamkan melalui fitur PayLater merupakan dana yang disalurkan oleh Findaya dari para pemberi pinjaman yang bekerjasama dengan Findaya. Dalam mengelola PayLater Gojek perlu bekerjasama dengan Findaya karena Gojek tidak memiliki izin untuk melakukan usaha pemberian fasilitas pinjam meminjam berbasis teknologi informasi sehingga dapat diketahui pula bahwa pengelolaan PayLater merupakan tanggungjawab dari Findaya

Hubungan hukum yang terjadi antara para pihak dalam penggunaan fitur PayLater pada aplikasi Gojek yaitu Pemberi pinjaman memberikan kuasa kepada Findaya sebagai penyelenggara pinjaman P2P untuk menyalurkan serta melakukan tindakan tertentu untuk menagih utang dari penerima pinjaman. Para pemberi pinjaman adalah orang, badan usaha dan/atau badan hukum yang memiliki piutang dari Layanan Pinjam Meminjam Uang Berbasis Teknologi Informasi. Findaya merupakan penyelenggara pinjaman P2P yang bekerjasama dengan Gojek dalam mengelola PayLater pada aplikasi Gojek, Findaya sebagai penyelenggara pinjaman P2P bertugas untuk mempertemukan dan menyalurkan dana dari pemberi pinjaman kepada penerima pinjaman atau pengguna metode pembayaran PayLater. Penerima pinjaman adalah pengguna aplikasi Gojek yang melakukan pembayaran layanan menggunakan metode pembayaran PayLater dan hanya dapat menggunakan dana pinjaman tersebut untuk tagihan layanan dari aplikasi Gojek. Gojek dalam hal ini merupakan penyedia layanan yang menyediakan metode pembayaran PayLater.

Hubungan hukum yang terdapat dalam penggunaan fitur PayLater pada aplikasi Gojek adalah hubungan hukum antara Gojek dengan pengguna PayLater karena dengan menggunakan layanan dalam aplikasi Gojek maka pengguna memiliki hubungan hukum dengan Gojek sebagai konsumen dan pelaku usaha, selain itu terdapat hubungan hukum kerjasama antara Gojek dengan Findaya dalam pengelolaan PayLater, lalu terdapat hubungan hukum pemberian kuasa antara para pemberi pinjaman dengan Findaya ketika pemberi pinjaman menitipkan dana yang dimilikinya untuk disalurkan kepada penerima pinjaman, selain 
Nisrina Anrika: Perlindungan Hukum Bagi...

itu para pemberi pinjaman juga memiliki hubungan hukum pinjam meminjam dengan penerima pinjaman. Findaya sebagai pelaku usaha memiliki hubungan hukum usaha dengan pengguna PayLater sebagai konsumen yang menerima pinjaman dana dari pemberi pinjaman.

POJK nomor 77 tahun 2016 pasal 18 menyebutkan bahwa hubungan kontraktual dalam pinjaman P2P hanya meliputi perjanjian antara Penyelenggara Pinjaman P2P (dalam hal ini Findaya) dengan pemberi pinjaman dan antara pemberi pinjaman dengan penerima pinjaman, padahal Findaya dalam hal ini selain menjadi penerima kuasa dari para pemberi pinjaman dan mewakili segala tindakan pemberi pinjaman juga merupakan pelaku usaha yang memiliki hubungan hukum dengan penerima pinjaman sebagai konsumen karena dalam memberikan layanan penyaluran dana dari pemberi pinjaman Findaya sebagai penyelenggara menetapkan biaya pelayanan, hal ini menunjukkan bahwa pelayanan yang diberikan oleh Findaya dimaksudkan untuk mencari keuntungan yang membuat Findaya termasuk dalam karakteristik pelaku usaha sehingga tidak tepat apabila hubungan hukum antara Findaya sebagai pelaku usaha dan penerima pinjaman sebagai konsumen tidak disertakan dalam peraturan yang mengatur mengenai pinjaman P2P yaitu POJK nomor 77 tahun 2016.

Findaya dalam penggunaan PayLater merupakan penyelenggara layanan pinjam meminjam hal ini sesuai dengan pasal 1 angka 6 POJK nomor 77 tahun 2016 yang menyebutkan pengertian dari penyelenggara adalah badan hukum Indonesia yang menyediakan, mengelola, dan mengoperasikan layanan pinjam meminjam uang berbasis teknologi informasi. Findaya merupakan perusahaan yang mempertemukan kebutuhan penerima pinjaman dengan para pemberi pinjaman dan menyalurkan dana dari pihak satu ke pihak yang lain, apabila dikaitkan dengan pengertian pelaku usaha dalam asal 1 angka 3 UUPK yang menjelaskan bahwa pelaku usaha adalah setiap orang perseorangan atau badan usaha di Indonesia yang secara sendiri maupun bersama-sama melakukan kegiatan usaha dalam berbagai bidang ekonomi maka dapat dikatakan bahwa Findaya merupakan pelaku usaha. Pelaku usaha dalam UUPK meliputi produsen, 
pendistribusi, media pengiklan, serta pedagang retail. ${ }^{5}$ Produk yang ditawarkan oleh Findaya adalah layanan maka dapat dikatakan bahwa Findaya merupakan pelaku usaha yang bergerak dalam bidang jasa. Hal ini sesuai dengan pengertian mengenai jasa pada pasal 1 angka 5 UUPK yaitu layanan yang berbentuk pekerjaan atau prestasi yang disediakan bagi masyarakat untuk dimanfaatkan oleh konsumen.

Konsumen berdasarkan pasal 1 angka 2 UUPK adalah setiap orang pemakai barang dan/atau jasa yang tersedia di masyarakat untuk kepentingan diri sendiri, keluarga, orang lain, maupun makhluk hidup lain dan tidak untuk diperdagangkan. Dalam kepustakaan ekonomi dikenal dua jenis konsumen yaitu konsumen antara dan konsumen akhir. Konsumen antara adalah konsumen yang mengolah kembali barang yang telah didapatnya untuk kemudian dijual kembali sedangkan konsumen akhir adalah pengguna terakhir dari suatu barang yang menggunakan barang yang didapatnya untuk kepentingan dirinya sendiri. Sebagai contoh apabila seseorang membeli roti dan memakannya sampai habis maka ia dapat dikategorikan sebagai konsumen akhir sedangkan apabila seseorang membeli roti kemudian menjual kembali roti tersebut dan mendapat keuntungan dari penjualan roti maka ia dapat dikatakan sebagai konsumen antara karena bukan merupakan penikmat dari fungsi utama roti sebagai makanan. Konsumen yang termasuk ke dalam ruang lingkup UUPK adalah konsumen akhir karena pasal 1 angka 2 UUPK menegaskan bahwa konsumen adalah setiap orang yang tidak memperdagangkan barang dan/atau jasa yang didapatkannya sehingga keuntungan yang didapatkan dari barang dan/atau jasa tersebut merupakan keuntungan yang berasal dari fungsi utama barang dan/atau jasa tersebut.

UUPK menyebutkan bahwa yang termasuk konsumen akhir adalah setiap orang atau subjek perorangan maka dalam penggunaan PayLater pada aplikasi Gojek yang paling tepat untuk dikategorikan sebagai kosumen adalah pengguna PayLater atau penerima pinjaman karena pengguna aplikasi Gojek adalah subjek

${ }^{5}$ al . Sri Handajani, [et.al], Buku Ajar Hukum Perlindungan Konsumen (Fakultas Hukum Universitas Airlangga 2006).17]. 
Nisrina Anrika: Perlindungan Hukum Bagi...

perorangan selain itu pengguna PayLater hanya dapat menggunakan pinjaman dari PayLater untuk membayar layanan pada aplikasi Gojek saja sehingga pengguna PayLater merupakan pemanfaat terakhir dari pinjaman yang diberikan melalui PayLater. Pengguna PayLater sebagai subjek perorangan dapat diketahui dari kebijakan Gojek yang mewajibkan pengguna yang ingin mengupgrade fitur Gopay (salah satu syarat untuk mendapatkan fitur PayLater) untuk mengunggah foto Kartu Tanda Penduduk (KTP) sebagai tanda bukti bahwa pengguna telah memenuhi persyaratan dan dari kebijakan tersebut dapat diketahui pula bahwa pengguna PayLater adalah perorangan karena yang dapat memiliki KTP adalah subjek perorangan.

\section{Perjanjian dalam penggunaan fitur PayLater pada Aplikasi Gojek}

Berdasarkan penjelasan dari sub bab sebelum ini dapat diketahui bahwa antara pemberi pinjaman dan penerima pinjaman terdapat hubungan hukum perjanjian pinjam meminjam seperti yang diatur dalam pasal 1754-1773 BW. Pasal 1754 BW menjelaskan bahwa pinjam meminjam adalah perjanjian yang membuat salah satu pihak memiliki kewajiban untuk memberikan pihak lain suatu jumlah tertentu barang yang habis karena pemakaian dan pihak yang lain memiliki kewajiban untuk mengembalikan barang yang dipinjamkan tersebut dengan jumlah yang sama dan keadaan yang sama. Dapat diketahui pula bahwa pengguna PayLater merupakan konsumen dari jasa yang ditawarkan oleh Findaya karena pengguna PayLater menikmati layanan jasa penyaluran dana dari Findaya sehingga pernyataan mengenai hubungan hukum yang terjadi dalam perjanjian P2P hanya terbatas pada hubungan hukum antara pemberi pinjaman dan penerima pinjaman serta pemberi pinjaman dengan penyelenggara pinjaman P2P adalah tidak tepat karena pengguna PayLater sebagai konsumen juga memiliki hubungan hukum dengan Findaya sebagai pelaku usaha.

Hubungan kontraktual antara pengguna PayLater dengan Findaya sebagai penerima kuasa dari pemberi pinjaman maupun Findaya sebagai pelaku usaha penyediaan jasa dituangkan dalam suatu kontrak baku. Penggunaan kontrak 
baku banyak ditemukan karena dianggap mempermudah proses transaksi antara pelaku usaha dan konsumen namun hal ini juga menunjukkan bahwa terdapat ketidakseimbangan posisi antara pelaku usaha dengan konsumen terutama dalam kebebasan membentuk isi kontrak. Hubungan kontraktual antara konsumen dan pelaku usaha dikenal dengan sebutan kontrak konsumen karena kedudukan para pihak dalam kontrak ini tidak seimbang. ${ }^{6}$ Keseimbangan para pihak dapat diketahui melalui ada atau tidaknya proses negosiasi dalam pembuatan kontrak antara para pihak. ${ }^{7}$ Kontrak yang dibentuk dari negosiasi menunjukkan bahwa para pihak memiliki kedudukan yang setara dan masing-masing memiliki keleluasaan dalam memberi masukan terhadap kontrak yang akan mengikatnya, kontrak ini dikenal dengan kontrak komersial. Sedangkan keberadaan kontrak baku menunjukkan bahwa tidak terdapat negosiasi dalam proses pembuatan kontrak, kontrak dibentuk oleh salah satu pihak dan pihak lain hanya memiliki pilihan untuk menerima atau menolak keseluruhan dari kontrak tersebut, kontrak ini juga dikenal dengan sebutan kontrak konsumen. Dalam kontrak konsumen keberadaan asas keseimbangan sulit diwujudkan karena terdapat ketimpangan kedudukan antara pelaku usaha dan konsumen. ${ }^{8}$

Perjanjian antara pelaku usaha dan konsumen diatur dalam UUPK namun dalam perjanjian tersebut berlaku pula ketentuan-ketentuan umum seperti syarat sah perjanjian yang diatur dalam BW. Suatu perjanjian dapat dikatakan sah dan berlaku apabila memenuhi syarat-syarat perjanjian yang diatur dalam pasal 1320 BW yaitu terdapat kesepakatan antara para pihak, kecakapan hukum dari pihak yang bersepakat, adanya suatu hal tertentu yang diperjanjikan, dan adanya suatu sebab yang halal.

\section{Tanggung gugat para pihak dalam perjanjian pinjam meminjam}

Pengaturan mengenai perjanjian pinjam meminjam belum diatur dalam suatu undang-undang khusus maka dari itu ketentuan mengenai perjanjian tersebut

${ }^{6} \mathrm{Al}$. Jonnery Bukit, [et.al], 'Eksistensi Asas Keseimbangan Pada Kontrak Konsumen di Indonesia' (2018) 14 DIH Jurnal Ilmu HUkum.[25].

7 ibid.[24].

8 ibid.[25]. 
Nisrina Anrika: Perlindungan Hukum Bagi...

termasuk mengenai tanggung gugat para pihak mengikuti ketentuan dalam BW. Pada dasarnya dengan adanya suatu perjanjian maka para pihak memiliki kewajiban untuk memenuhi suatu prestasi dari pihak lain yaitu berupa memberikan sesuatu, berbuat sesuatu, atau tidak melakukan sesuatu, apabila terdapat pihak yang tidak memenuhi prestasi maka dianggap melakukan wanprestasi atau ingkar janji. Menurut Subekti wanprestasi oleh debitur atau si berutang dapat berupa empat macam yaitu a) tidak melakukan yang diperjanjikan, b) melaksanakan yang diperjanjikan tetapi tidak sepenuhnya, c) terlambat memenuhi yang diperjanjikan, atau d) melakukan sesuatu yang tidak diperbolehkan dalam perjanjian. ${ }^{9}$ Dalam Pasal 1239 BW disebutkan bahwa dalam suatu perikatan apabila debitur tidak memenuhi kewajibannya maka penyelesaiannya dapat berupa kewajiban memberikan penggantian biaya, rugi, dan bunga. Pihak yang prestasinya tidak dipenuhi atau dalam BW disebut sebagai berpiutang atau kreditur menurut Pasal 1240 BW dapat meminta untuk menghapuskan perjanjian dengan tidak mengurangi hak menuntut penggantian biaya, rugi, dan bunga jika ada alasan untuk itu.

Keadaan ingkar janji atau wanprestasi tidak terjadi dengan sendirinya, hal ini disebutkan dalam Pasal 1243 BW yaitu penggantian biaya, rugi dan bunga karena tidak dipenuhinya suatu perikatan baru diwajibkan setelah si berutang tetap melalaikan kewajibannya bahkan setelah diberikan peringatan mengenai kelalaiannya. Pasal 1238 BW juga menyebutkan bahwa seseorang dianggap lalai apabila dengan surat perintah atau akta sejenis itu telah dinyatakan lalai atau dalam perikatannya disebutkan bahwa dengan lewatnya waktu pemenuhan prestasi maka dianggap lalai, untuk menyatakan seseorang wanprestasi dan memiliki kewajiban untuk bertanggung gugat sebelumnya perlu dilakukan pemberitahuan terlebih dahulu atau yang juga dikenal dengan sebutan somasi oleh kreditur atau juru sita kepada debitur minimal sebanyak tiga kali bahwa ia telah melalaikan kewajibannya dan harus memenuhi kewajibannya untuk jangka waktu tertentu. ${ }^{10}$

9 Sri Redjeki Slamet, 'Tuntutan Ganti Rugi Dalam Perbuatan Melawan Hukum: Suatu Perbandingan Dengan Wanprestasi' (2013) 10 Lex Jurnalica.[114].

${ }^{10}$ Karina pramithasari, 'Analisis Yuridids Terhadap Wanprestasi Perjanjian Jual Beli Tanah Di Kota Batam’ (2016) 3 Jurnal Petita.[178]. 
Sampai waktu yang telah ditentukan dalam peringatan tersebut apabila debitur masih belum memenuhi kewajibannya maka kreditur dapat mengajukan gugatan ke pengadilan dengan menggunakan surat peringatan tersebut sebagai bukti bahwa debitur telah melakukan wanprestasi namun tidak semua perjanjian memerlukan somasi terlebih dahulu untuk menyatakan bahwa seseorang telah wanprestasi. Perjanjian yang telah ditentukan jangka waktunya apabila jangka waktu telah lewat dan prestasi belum dipenuhi maka debitur sudah dianggap melakukan wanprestasi. ${ }^{11}$ Somasi menurut Yurisprudensi MA 1 Juli 1959 no. 186 K/Sip/1959 harus berbentuk tertulis dan tidak perlu dalam akta otentik. ${ }^{12}$

Terbentuknya perjanjian antara pengguna PayLater dengan pemberi pinjaman membuat para pihak memiliki kewajiban untuk memenuhi prestasi yaitu menyalurkan dana pinjaman dan mengembalikan dana tersebut apabila terdapat pihak yang tidak memenuhi perjanjian tersebut pihak yang dirugikan dapat menggugat ganti rugi melalui pengadilan atas dasar wanprestasi namun sebelum mengajukan gugatan ke pengadilan pihak yang dirugikan harus mengirimkan surat peringatan atau somasi terlebih dahulu mengenai kelalaian dari debitur, apabila setelah pemberitahuan tersebut pihak yang lalai masih tidak menunjukkan iktikad baik untuk menyelesaikan kewajibannya maka pihak yang dirugikan dapat menuntut ganti rugi melalui pengadilan dengan menggunakan somasi tersebut sebagai salah satu bukti bahwa tergugat telah melakukan wanprestasi dan memiliki kewajiban untuk bertanggung gugat terhadap kelalaiannya tersebut.

Dalam perjanjian pinjaman P2P yang dilakukan melalui PayLater dalam aplikasi Gojek telah disebutkan bahwa Pemberi pinjaman memberikan kuasa kepada Findaya untuk mengambil tindakan yang berhubungan dengan penagihan maka dari itu gugatan ganti rugi dari pemberi pinjaman dilakukan oleh Findaya sebagai penerima kuasa.

11 J. Satrio, 'Beberapa Segi Hukum Tentang Somasi (Bagian I)' (2010) <www.hukumonline.com> accessed 30 November 2019.

12 ibid. 
Nisrina Anrika: Perlindungan Hukum Bagi...

\section{Tanggung gugat Pelaku Usaha}

Pelaku usaha sebagai pihak yang lebih mengenal produk yang ditawarkan kepada konsumennya bertanggungjawab untuk memberikan informasi yang sebenar-benarnya kepada konsumen maka dari itu apabila terdapat ketidaksesuaian antara informasi yang diberikan dengan pengalaman yang dirasakan oleh konsumen dalam mengkonsumsi atau menggunakan suatu produk menjadi tanggungjawab pelaku usaha selama pelaku usaha tidak dapat membuktikan bahwa ketidaksesuaian tersebut diakibatkan oleh kelalaian dari konsumen itu sendiri.

Dalam perjanjian konsumen apabila terdapat konsumen yang merasa dirugikan karena produk yang didapatkannya tidak sesuai dengan informasi yang diberikan oleh pelaku usaha dapat meminta ganti rugi secara langsung kepada pelaku usaha, hal ini diatur dalam pasal 19 UUPK dengan pembatasan penuntutan ganti rugi secara langsung dapat dilakukan paling lambat 7 hari setelah tanggal transaksi. Ahmadi Miru dan Sutarman Yodo dalam bukunya menyebutkan bahwa tanggung jawab pelaku usaha tidak hanya terbatas pada cacat pada suatu produk tetapi juga meliputi segala kerugian yang dialami konsumen. ${ }^{13}$

Tuntutan ganti kerugian oleh konsumen yang merasa dirugikan kepada pelaku usaha tidak hanya terbatas pada pengajuan tuntutan ganti rugi secara langsung saja apabila setelah diajukan tuntutan ganti rugi kepada pelaku usaha namun pelaku usaha tidak merespon tuntutan tersebut maka konsumen dapat menggugat pelaku usaha di Badan Penyelesaian Sengketa Konsumen (BPSK) atau badan peradilan di tempat kedudukan konsumen, hal ini diatur dalam pasal 23 UUPK, selain itu kebebasan dalam penyelesaian sengketa juga disebutkan kembali pada pasal 45 ayat (2) UUPK yang menyebutkan bahwa penyelesaian sengketa konsumen dapat ditempuh melalui pengadilan atau diluar pengadilan berdasarkan pilihan sukarela para pihak bersengketa.

Pasal 46 ayat (1) UUPK menyebutkan bahwagugatan atas pelanggaran pelaku usaha dapat dilakukan oleh seorang konsumen, kelompok konsumen, lembaga

${ }^{13} \mathrm{Al}$. Ahmadi Miru, [et., Hukum Perlindungan Konsumen Edisi Revisi (Rajagrafindo Persada 2015).[130]. 
perlindungan konsumen swadaya masyarakat, dan pemerintah. Ayat (2) UUPK menyebutkan bahwa gugatan oleh sekelompok konsumen, lembaga perlindungan konsumen, swadaya masyarakat atau pemerintah dapat diajukan kepada Peradilan Umum. Ayat (2) pasal tersebut tidak menyertakan seorang konsumen sebagai pihak yang dapat mengajukan tuntutan kepada peradilan umum karena seorang konsumen memiliki pilihan lain sebelum mengajukan tuntutan kepada peradilan umum yaitu tuntutan langsung kepada pelaku usaha dan tuntutan melalui BPSK. Tuntutan yang ditujukan melalui BPSK dapat dilakukan oleh seorang konsumen dengan menggunakan dasar gugatan perbuatan melanggar hukum atas tindakan pelaku usaha yang melanggar ketentuan-ketentuan dalam UUPK. Berdasarkan pasal 52 huruf a UUPK penyelesaian sengketa di BPSK dapat dilakukan dengan cara mediasi, konsiliasi, atau arbitrase. Pengaturan mengenai penyelesaian sengketa melalui BPSK diatur secara lebih lanjut dalam Keputusan Menteri perindustrian dan perdagangan republik Indonesia nomor 350/MPP/Kep/12/2001 tentang pelaksanaan tugas dan wewenang badan penyelesaian sengketa konsumen. Pada pasal 4 ayat (2) Keputusan Menteri tersebut disebutkan bahwa cara penyelesaian sengketa alternatif yang terdapat dalam BPSK bukan merupakan suatu proses berjenjang melainkan suatu pilihan dan pemilihan cara penyelesaian sengketa dilakukan oleh para pihak namun, apabila tidak ditemukan kesepakatan terhadap cara penyelesaian maka pilihan konsumen akan diutamakan. ${ }^{14}$

Penyelesaian sengketa di BPSK selalu dituangkan dalam bentuk putusan BPSK yang dapat berupa perdamaian, gugatan ditolak, atau gugatan dikabulkan. Putusan BPSK merupakan putusan final dan mempunyai kekuatan hukum tetap sehingga putusan tersebut mengikat para pihak dan tidak dapat diajukan upaya banding namun pasal 56 ayat (2) UUPK menyebutkan bahwa terhadap keputusan BPSK dapat diajukan keberatan kepada Pengadilan Negeri. Keberatan terhadap putusan BPSK yang diajukan ke Pengadilan Negeri tidak dapat diajukan upaya hukum banding namun dapat dilakukan kasasi ke Mahkamah Agung.

${ }^{14}$ Antonius Suhadi, 'Penyelesaian Sengketa Konsumen Melalui Mekanisme Konsiliasi, Mediasi, Arbitrase Pada Badan Penyelesaian Sengketa Konsumen’ (Universitas Sriwijaya 2009). [58]. 
Nisrina Anrika: Perlindungan Hukum Bagi...

Penjelasan diatas menunjukkan bahwa seorang konsumen yang merasa dirugikan dapat menuntut hak nya kepada pelaku usaha melalui tuntutan langsung, BPSK maupun Peradilan Umum. Namun apabila konsumen tersebut memilih untuk menggugat pelaku usaha melalui Peradilan Umum maka konsumen tidak dapat menjadikan pelanggaran terhadap UUPK sebagai dasar gugatan. Gugatan yang diajukan ke Peradilan Umum dapat menggunakan dasar hukum wanprestasi atas perjanjian para pihak.

POJK nomor 1 tahun 2014 menyebutkan bahwa penyelesaian segketa pada sektor keuangan dapat diselesaikan melalui Lembaga Alternatif Penyelesaian Sengketa, pada dasarnya lembaga ini merupakan bentuk lain dari Badan Penyelesaian Sengketa. Prosedur pengaduan sengketa dalam Lembaga Alternatif Penyelesaian Sengketa memiliki kemiripan dengan prosedur pengaduan kepada BPSK yaitu konsumen terlebih dahulu harus mengadukan keluhannya kepada lembaga jasa keuangan yang bersangkutan, apabila cara tersebut telah ditempuh namun tidak terbentuk kesepakatan maka konsumen atau lembaga jasa keuangan dapat melanjutkan penyelesaian sengketa di luar pengadilan melalui Lembaga Alternatif Penyelesaian Sengketa ataupun melalui pengadilan. Dibentuknya lembaga ini dimaksudkan agar terdapat lembaga penyelesaian sengketa khusus dalam sengketa yang berhubungan dengan sektor jasa keuangan.

\section{Tanggung gugat Konsumen}

Pengaturan dalam UUPK tidak hanya ditujukan untuk melindungi hak-hak konsumen karena tujuan dari diadakannya UUPK adalah untuk memberi manfaat sebesar-besarnya bagi para pihak maka terdapat pula pengaturan yang melindungi hak dari pelaku usaha. Pasal 6 huruf a UUPK menyebutkan bahwa pelaku usaha memiliki hak untuk mendapat pembayaran sesuai dengan kesepakatan. UUPK tidak menjelaskan mengenai penegakkan hak tersebut namun dengan adanya pengaturan tersebut menunjukkan bahwa pelaku usaha dapat menegakkan hak nya apabila terdapat konsumen yang memiliki iktikad buruk. 
Penegakkan hak pelaku usaha juga dapat dilihat dalam pasal 5 huruf $d$ UUPK yang menyebutkan bahwa konsumen memiliki kewajiban untuk mengikuti upaya penyelesaian hukum sengketa perlindungan konsumen secara patut. UUPK tidak menjelaskan mengenai cara penyelesaian sengketa yang dapat dilakukan oleh pelaku usaha namun dapat diketahui bahwa pelaku usaha dapat menggugat ganti rugi kepada konsumen dan konsumen memiliki kewajiban untuk mengikuti upaya penyelesaian sengketa yang diajukan oleh pelaku usaha.

POJK nomor 1 tahun 2014 juga menyebutkan bahwa konsumen dan lembaga jasa keuangan dapat melakukan penyelesaian sengketa di luar pengadilan melalui Lembaga Alternatif Penyelesaian Sengketa maupun melalui pengadilan. Hal ini menunjukkan bahwa pelaku usaha juga memiilki hak untuk melakukan penyelsaian sengketa melalui Lembaga Alternatif Penyelesaian Sengketa. UUPK juga tidak melarang pelaku usaha untuk melakukan upaya penyelesaian sengketa menggunakan cara yang disediakan untuk konsumen maka dari itu pelaku usaha juga dapat mengajukan upaya penyelesaian sengketa melalui BPSK dan Pengadilan Negeri.

\section{Kesimpulan}

Terdapat hubungan hukum kerjasama antara Gojek dengan Findaya dalam mengelola Fitur PayLater, hubungan hukum pemberian kuasa antara Findaya dengan Pemberi pinjaman, hubungan hukum pinjam meminjam antara pemberi pinjaman dengan pemberi pinjaman, dan hubungan hukum antara Findaya sebagai pelaku usaha dengan penerima pinjaman atau pengguna PayLater sebagai konsumen.

Upaya hukum yang dapat dilakukan oleh Pemberi pinjaman apabila merasa dirugikan oleh penerima pinjaman dapat menggugat ganti rugi atas dasar wanprestasi dengan diwakilkan oleh Findaya sebagai penerima kuasa atas dana yang disalurkan oleh pemberi pinjaman. Konsumen dan Pelaku usaha yang merasa dirugikan oleh satu sama lain dapat melaksanakan penyelesaian sengketa melalui BPSK, Lembaga Alternatif Penyelesaian Sengketa, dan Pengadilan Negeri. 
Nisrina Anrika: Perlindungan Hukum Bagi...

\section{Daftar bacaan}

\section{Buku}

Ahmadi Miru, [et. A., Hukum Perlindungan Konsumen Edisi Revisi (Rajagrafindo Persada 2015).

Sri Handajani, [et. al. ., Buku Ajar Hukum Perlindungan Konsumen (Fakultas Hukum Universitas Airlangga 2006).

\section{Thesis}

Antonius Suhadi, 'Penyelesaian Sengketa Konsumen Melalui Mekanisme Konsiliasi, Mediasi, Arbitrase Pada Badan Penyelesaian Sengketa Konsumen' (Universitas Sriwijaya 2009).

\section{Jurnal}

Jonnery Bukit, [et. A., 'Eksistensi Asas Keseimbangan Pada Kontrak Konsumen Di Indonesia' (2018) 14 DIH Jurnal Ilmu HUkum.

Karina pramithasari, 'Analisis Yuridids Terhadap Wanprestasi Perjanjian Jual Beli Tanah Di Kota Batam' (2016) 3 Jurnal Petita.

Ratna Hartanto [et. al. ., 'Hubungan Hukum Para Pihak Dalam Peer to Peer Lending' (2008) 25 Jurnal Hukum Ius Quia Iustum.

Sri Redjeki Slamet, 'Tuntutan Ganti Rugi Dalam Perbuatan Melawan Hukum: Suatu Perbandingan Dengan Wanprestasi' (2013) 10 Lex Jurnalica.

\section{Laman}

Gojek, 'PayLater' https://www.gojek.com/PayLater/.

J. Satrio, 'Beberapa Segi Hukum Tentang Somasi (Bagian I)’ (2010) <www. hukumonline.com> accessed 30 November 2019.

Otoritas Jasa Keuangan, 'Daftar Perusahaan Fintech Lending Berizin Dan Terdaftar Di OJK per 7 Agustus 2019' (2019) www.ojk.go.id.

\section{Perundang-undangan}

Kitab Undang-undang Hukum Perdata Staatsblad 1847 Nomor 23 tentang Burgerlijk Wetboek VoorIndonesie (BW).

Herzien Inlandsch Reglement (HIR) Staatsblad Tahun 1941 No. 44. 
Undang-undang Dasar Negara Republik Indonesia Tahun 1945.

Yurisprudensi Mahkamah Agung 1 juli 1959 no. 186 K/Sip/1959.

Surat Edaran Mahkamah Agung Nomor 3 Tahun 1963.

Undang-Undang Nomor 1 tahun 1974 tentang Perkawinan (Lembaran Negara Republik Indonesia tahun 1974 No. 1 Tambahan Lembaran Negara Republik Indonesia No. 3019).

Undang-undang nomor 8 tahun 1999 tentang Perlindungan Konsumen (Lembaran Negara Republik Indonesia tahun 1999 No. 42 Tambahan Lembaran Negara Republik Indonesia No.3821).

Keputusan Menteri perindustrian dan perdagangan republik Indonesia nomor 350/MPP/Kep/12/2001 tentang pelaksanaan tugas dan wewenang badan penyelesaian sengketa konsumen.

Undang-Undang Nomor 35 Tahun 2014 tentang Perubahan atas UndangUndang Nomor 23 Tahun 2002 tentang Perlindungan Anak (Lembaran Negara Republik Indonesia tahun 2014 No. 297 Tambahan Lembaran Negara Republik Indonesia No. 5606).

Peraturan Otoritas Jasa Keuangan nomor 1 tahun 2014 tentang Lembaga Alternatif Penyelesaian Sengketa di Sektor Jasa Keuangan (Lembaran Negara Republik Indonesia tahun 2014 No. 12 Tambahan Lembaran Negara Republik Indonesia No. 5499).

Peraturan Otoritas Jasa Keuangan nomor 77 tahun 2016 tentang Lembaga Pinjam Meminjam Uang berbasis teknologi Informasi (Lembaran Negara Republik Indonesia tahun 2016 No. 324 Tambahan Lembaran Negara Republik Indonesia No. 6005).

Peraturan Otoritas Jasa Keuangan nomor 12 tahun 2017 tentang Penerapan Program Anti Pencucian Uang dan Pencegahan Pendanaan Terorisme di Sektor Jasa Keuangan (Lembaran Negara Republik Indonesia tahun 2017 No. 57 Tambahan Lembaran Negara Republik Indonesia No. 6035).

Undang-Undang Nomor 16 tahun 2019 tentang Perubahan atas Undangundang Nomor 1 Tahun 1974 tentang Perkawinan (Lembaran Negara Republik Indonesia tahun 2019 No. 186 Tambahan Lembaran Negara Republik Indonesia No. 6401).

How to cite: Nisrina Anrika Nirmalapurie, 'Perlindungan Hukum Bagi Para Pihak Dalam Penggunaan Fitur PayLater Pada Aplikasi Gojek' (2020) Vol. 3 No. 1 Media Iuris. 
--Halaman ini sengaja dibiarkan kosong-- 